\title{
ANALISIS MINAT MAHASISWA MENDENGARKAN APLIKASI MUSIK BERBAYAR DAN UNDUHAN MUSIK GRATIS
}

\section{Analysis of Student Interest in Listening to Paid Music Applications and Free Music Downloads}

\author{
Johannes Fernandes Andry ${ }^{1)}$, Calvin Tjee ${ }^{2)}$ \\ ${ }^{1,2)}$ Program Studi Sistem Informasi, Universitas Bunda Mulia, Jakarta \\ Diterima 18 Juli 2019 / Disetujui 14 Agustus 2019
}

\begin{abstract}
Nowadays, music has already become one of people's life styles. People could download music from websites. However they don't know whether the music that they have downloaded is authentic from the producer or not. People should listen to authentic music. And the appearance of Spotify, music streaming application, allow people to listen to music with guaranteed sound quality because Spotify has the copyright for musics that they have uploaded. To enjoy the Spotify's services, users are obligated to pay the monthly service fee. On the other hand, Spotify offers one month free service to new users that have registered on Spotify's Website. Based on these explanations, the purpose of this research is to know about how big does the interest of XYZ University's Student from all majors in paid music streaming application especially Spotify and free downloaded music via website. The methods that is being use in this research is quantitative method with purposive sampling technique which is to distribute questionnaire to the students. After distributed the questioners, researcher is going to analyze the data with validity test, reliability test and hypothesis test by using SPSS software. The research result shows that people is interested in using paid music application.
\end{abstract}

Keywords: Music, Application, Spotify, Interest

\begin{abstract}
ABSTRAK
Musik sekarang ini sudah menjadi gaya hidup masyarakat sehari-hari. Dimana masyarakat mengunduh musik melalui internet/website. Akan tetapi masyarakat tidak tahu apakah musik yang diunduh melalui internet itu apakah asli dari produser musik atau tidak. Musik yang baik untuk didengar adalah musik yang asli/original. Dan sekarang dengan adanya aplikasi streaming musik Spotify pengguna bisa mendengarkan musik yang kualitas suaranya sudah terjamin karena, Spotify adalah penyedia hak cipta atas musik yang diunggah. Untuk menikmati layanan aplikasi streaming musik Spotify, pengguna diharuskan membayar layanan secara bulanan, namun Spotify menawarkan layanan gratus atau free dengan jangka waktu 30 hari bagi pengguna baru yang mendaftar di Website Spotify tersebut. Berdasarkan uraian tersebut, tujuan dari penelitian ini adalah untuk mengetahui seberapa besar minat mahasiswa dari Universitas XYZ pada seluruh jurusan dan seluruh angkatan terhadap layanan aplikasi musik berbayar khususnya aplikasi Spotify dan unduhan musik secara gratis melalui website. Metode penelitian yang dipakai dalam penelitian minat ini adalah metode kuantitatif dengan teknik purposive sampling dengan cara menyebarkan kuesioner. Setelah menyebarkan kuesioner, peneliti akan menganalisis data dengan uji validitas, uji reliabilitas dan uji hipotesis dengan menggunakan alat bantu komputer yaitu software SPSS. Hasil penelitian minat ini terlihat aplikasi musik Spotify berbayar lebih banyak di minat.
\end{abstract}

Kata Kunci: Music, Aplikasi, Spotify, Minat

\footnotetext{
*Korespondensi Penulis:

E-mail: jf_andry@kreavindo.com
} 


\section{PENDAHULUAN}

Perkembangan teknologi sekarang ini semakin maju dan cepat, terutama teknologi aplikasi yang semakin canggih (Khairunizam, dkk, 2017). Hal ini membuat masyarakat untuk terus berusaha mengikuti/meniru perkembangan teknologi, sehingga tidak dikatakan sebagai seseorang yang ketinggalan zaman. Kemudahan untuk mengakses internet, membuat perubahan gaya hidup masyarakat (Kusumah, dkk, 2017). Musik adalah media ungkapan kesenian yang mencerminkan kebudayaan masyarakat (Pangastuti, 2015). Musik saat ini sudah menjadi bagian dalam kehidupan masyarakat sehari-hari (Sonang, 2013). Dimana masyarakat dapat mengunduh musik melalui internet/website. Tetapi banyaknya musik yang tersebar di internet tersebut adalah kualitas suara musik yang buruk. Oleh karena itu sekarang masyarakat tidak perlu mengunduh musik dari situs manapun. Penikmat musik cukup menggunakan aplikasi musik digital yang dapat diunduh oleh berbagai macam perangkat smartphone.

Aplikasi yang sedang populer bagi mahasiswa yang memiliki hobi menggemari musik saat ini adalah aplikasi musik Spotify. Spotify adalah suatu aplikasi musik digital asal mancanegara yang telah sukses meraih pasar di Indonesia ataupun dunia dan menyediakan hiburan musik yang legal yang digunakan secara streaming atau online (Kusumah, dkk, 2017). Spotify sudah menjadi penyedia hak cipta atas musik yang di upload/diunggah, dan membuat musik yang disediakan dapat dipastikan merupakan musik yang asli/original dan pengguna dapat menikmati beragam koleksi yang lengkap secara resmi. Spotify memungkinkan pengguna untuk dapat mendengarkan musik dari beberapa aliran musik dan artis baik lokal maupun internasional.

Spotify mempunyai dua model layanan, yaitu gratis (free) dan berbayar (premium). Pengguna dengan layanan free dan layanan premium mempunyai kualitas layanan yang berbeda. Spotify dengan layanan model premium dapat menghilangkan iklan, meningkatkan kualitas suara musik dan pengguna dapat mengunduh musik untuk dinikmati secara offline tanpa menggunakan kuota. Sedangkan, Spotify dengan model layanan gratis (free) tidak bisa menikmati fitur yang ada pada layanan premium.

Dalam penelitian sebelumnya yang pertama oleh Agus Purnomo (Purnomo, dkk, 2016). dengan judul "Pengembangan Aplikasi Info Lagu Nusantara Berbasis Android Untuk Melestarikan Warisan Budaya Indonesia" yang bertujuan untuk untuk melestarikan budaya Indonesia. siswa mengalami kesulitan menghafal lirik dan menyanyikan berbagai lagu nusantara. Dan hasil penelitiannya rata-rata responden menjawab $78 \%$ menjawab setuju dari total responden 19 orang pengguna.

Dalam penelitian sebelumnya yang kedua oleh Geoff Luck (Luck, 2016), dengan judul "The Psychology of Streaming: Exploring Music Listeners Motivation to Favour Access Over Ownership" yang mempunyai tujuan untuk meneliti digital streaming musik video tersendiri dan orang-orang dari pandangan psikologis. Dan hasilnya orang-orang lebih menyukai pencarian streaming musik video orang lain dari pada video tersendiri.

Tujuan dari penelitian ini adalah untuk mendapatkan gambaran mengenai minat mahasiswa dalam mendengarkan musik, apakah mahasiswa lebih memilih mendengarkan musik melalui aplikasi unduhan musik Spotify berbayar atau melalui unduhan musik dari internet/website secara gratis. Dalam penelitian ini, peneliti akan menggunakan metode purposive sampling dimana peneliti mengambil sampel berdasarkan populasi yang sudah diketahui sebelumnya 
(Sutanggi, 2014). Sampel dalam penelitian ini adalah mahasiswa dengan semua angkatan dan jurusan yang ada di Universitas XYZ.

\section{TINJAUAN PUSTAKA}

\section{A. Musik}

Musik adalah media ungkapan kesenian yang mencerminkan kebudayaan masyarakat oleh pendukungnya. Musik yang mempunyai arti ilmu seni menyusun suara diutarakan, hubungan temporal dan kombinasi untuk mempunyai hasil komposisi yang memberikan keseimbangan dan kesatuan nada yang disusun sedemikian rupa sehingga mengandung irama lagu dan keharmonisan (Pangastuti, 2015).

\section{B. Aplikasi}

Aplikasi adalah program yang dibuat untuk menjalankan suatu fungsi bagi pengguna aplikasi serta dapat digunakan untuk suatu sasaran yang akan dituju. Menurut kamus komputer eksekutif, pengertian aplikasi adalah memecahkan masalah yang menggunakan teknik pemrosesan data yang berpacu pada sebuah komputansi yang diharapkan maupun pemrosesan data (Juansyah, 2015).

\section{Minat}

Minat merupakan keinginan seseorang untuk melakukan suatu perilaku tertentu. Dapat dikatakan bahwa seseorang akan melakukan suatu hal tertentu apabila memiliki kemauan dari dalam diri untuk melakukannya. Sementara menurut Slameto menyatakan bahwa minat adalah suatu rasa yang lebih suka (senang) dan rasa ketertarikan pada suatu hal atau aktifivtas (Pibriana dan Ricoida, 2017).

\section{Spotify}

Spotify adalah sebuah aplikasi musik digital asal mancanegara yang lebih tepatnya asal swedia yang menyediakan musik yang legal secara online atau streaming (Kusumah, 2017). Spotify berperan dalam penyedia hak cipta atas musik yang di upload/diunggah, sehingga musik yang disajikan adalah musik resmi dan pengguna dapat menikmati beragam koleksi musik secara resmi. Melalui Spotify pengguna aplikasi dapat mendengarkan musik berbagai macam genre dan artis dari lokal sampai mancanegara. lalu, Spotify menawarkan dua model berlangganan yaitu gratis (free) dan berbayar (premium). Pengguna dengan layanan gratis (free) dan layanan premium mendapatkan layanan yang berbeda, Spotify dengan layanan premium dapat menghilangkan iklan, meningkatkan kualitas suara musik dan pengguna dapat mengunduh musik secara offline. Sedangkan Spotify gratis (free) tidak bisa menggunakan layanan yang ada pada premium. Spotify dapat digunakan untuk platform desktop (Windows dan Mac OS) dan mobile (Android dan iOS).

\section{E. Purposive Sampling}

Purposive sampling adalah mengambil sampel didasarkan pertimbangan tertentu yang digunakan oleh peneliti, berdasarkan ciri-ciri populasi yang sudah diketahui sebelumnya. Purposive Sampling adalah teknik menentukan sampel penelitian dengan beberapa pertimbangan yang tujuannya adalah data yang didapat nantinya bisa lebih representative (Sutanggi, 2014).

\section{METODE PENELITIAN}

\section{A. Tahapan Penelitian}

Penelitian ini dilakukan tahapan-tahapan berikut:

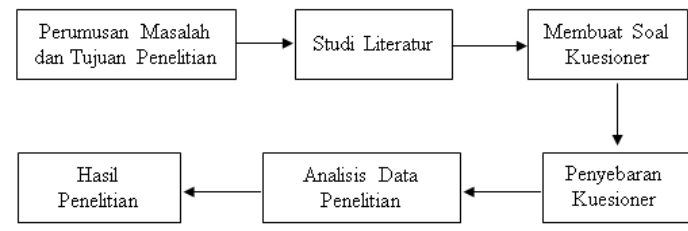

Gambar 1 Tahapan Penelitian 
Perumusan Masalah dan Tujuan Penelitian, pada tahapan ini peneliti mencari masalahmasalah dalam topik penelitian ini dan membuat tujuan dibuatnya penelitian ini.

Studi Literatur, mendapatkan sebuah informasi yang berkaitan dengan topik penelitian dari berbagai macam sumber antara lain jurnal dan buku maupun artikel.

Membuat Soal Kuesioner, membuat pertanyaan kuesioner yang akan diberikan ke mahasiswa Universitas Bunda Mulia. Penyebaran Kuesioner, melakukan penyebaran kuesioner ke mahasiswa Universitas Bunda Mulia dengan teknik Purposive Sampling.

Analisis Data Penelitian, setelah dikumpulkan hasil kuesioner peneliti akan menganalisis data penelitian dengan uji validitas, uji reliabilitas, dan uji hipotesis

Hasil Penelitian, dilakukan setelah menguji analisis data penelitian. Hasil dari penelitian ini akan memperlihatkan apakah mahasiswa lebih memilih mendengarkan musik melalui aplikasi unduhan musik Spotify berbayar atau melalui unduhan musik dari internet/website secara gratis.

\section{B. Metode Pengumpulan Data}

Pengumpulan data dalam penelitian ini dengan cara kuantitatif dimana peneliti akan menyebarkan kuesioner yang merupakan kumpulan pertanyaan yang telah disusun untuk mendapatkan informasi dari mahasiswa Universitas Bunda Mulia. Tujuannya adalah menterjemahkan informasi yang dibutuhkan peneliti ke dalam pertanyaan yang berspesifik sehingga responden mempunyai kemauan dalam menjawab pertanyaan.

\section{Model, Variabel, dan Indikator Penelitian}

Berdasarkan teori dan temuan hasil dari penelitian sebelumnya maka dibuat suatu model penelitian yang secara langsung menunjukkan hipotesis yang diajukan penelitian ini. Selain itu, dari model penelitian yang diajukan dapat diketahui hubungan dari mahasiswa terhadap minat penggunaan aplikasi musik berbayar dan unduhan musik secara gratis.

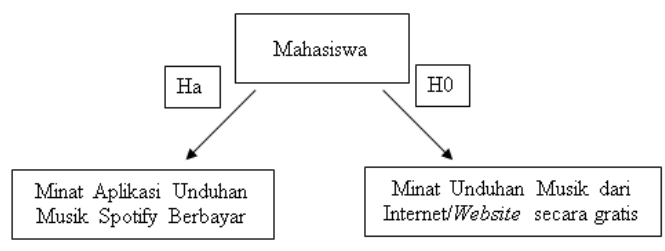

\section{Gambar 2 Model Penelitian}

Hipotesis pada penelitian ini adalah:

Ha: Minat mahasiswa dalam mendengarkan musik melalui aplikasi unduhan musik Spotify berbayar lebih besar dari pada minat unduhan musik dari internet/website secara gratis.

H0: Minat mahasiswa dalam mendengarkan musik melalui unduhan internet/website secara gratis lebih besar dari pada minat aplikasi unduhan musik Spotify berbayar.

Tabel 1 Variabel dan Indikator Penelitian

\begin{tabular}{|l|l|}
\hline \multicolumn{1}{|c|}{ Variabel } & \multicolumn{1}{c|}{ Indikator } \\
\hline Minat Aplikasi & -Kelengkapan daftar lagu \\
Unduhan Musik & pada aplikasi musik. \\
Spotify & -Mudah dalam penggunaan \\
Berbayar & $\begin{array}{l}\text { aplikasi musik. } \\
\text {-Kualitas suara musik yang } \\
\text { diunduh sudah terjamin asli. }\end{array}$ \\
\hline $\begin{array}{l}\text { Minat Unduhan } \\
\text { Musik dari }\end{array}$ & $\begin{array}{l}\text {-Tidak mengeluarkan biaya } \\
\text { dalam mengunduh musik. } \\
\text { Secara Gratis }\end{array}$ \\
& $\begin{array}{l}\text {-Sulit dalam mencari kualitas } \\
\text { suara musik yang } \\
\text { asli/original. }\end{array}$ \\
\hline
\end{tabular}

Adapun indikator masing-masing variabel dan simbol-simbol untuk butir dalam kuesioner ditunjukkan seperti pada Tabel 1.

\section{Metode Analisis Data}

Metode yang digunakan untuk menganalisis data adalah dengan metode uji validitas, uji reliabilitas, dan uji hipotesis. Dalam uji validitas peneliti akan menggunakan rumus "Pearson Product 
Moment", uji reliabilitas peneliti akan menggunakan rumus "Cronbach's Alpha", dan untuk uji hipotesis peneliti akan menggunakan Uji Independent Sample TTest untuk mengetahui dan membandingkan rata-rata dari dua variabel yang berbeda yaitu variabel pertama yang berisi minat mahasiswa mendengarkan musik melalui aplikasi unduhan musik Spotify berbayar dan variabel kedua yang berisi minat unduhan musik dari internet/website secara gratis.

\section{HASIL DAN PEMBAHASAN}

\section{A. Perancangan Kuesioner}

Berdasarkan indikator yang didapat dari model penelitian, indikator penelitian ini digunakan sebanyak 5 indikator dimana indikator ini akan menentukan banyaknya pertanyaan yang akan ditanyakan didalam kuesioner. Indikator tersebut ditunjukkan seperti pada Tabel 2.

\section{Tabel 2 Rancangan Kuesioner}

\begin{tabular}{|c|c|c|c|}
\hline Variabel & $\begin{array}{c}\text { Nomor } \\
\text { Pertan } \\
\text { yaan }\end{array}$ & Indikator & $\begin{array}{c}\text { Simb } \\
\text { ol }\end{array}$ \\
\hline $\begin{array}{l}\text { Minat } \\
\text { Aplikasi } \\
\text { Unduhan } \\
\text { Musik } \\
\text { Spotify } \\
\text { Berbayar }\end{array}$ & 1 & $\begin{array}{l}\text { Kelengkapan } \\
\text { daftar lagu pada } \\
\text { aplikasi musik. } \\
\text {-Mudah dalam } \\
\text { penggunaan } \\
\text { aplikasi musik. } \\
\text {-Kualitas suara } \\
\text { musik yang } \\
\text { diunduh sudah } \\
\text { terjamin asli. }\end{array}$ & $\begin{array}{l}\text { MB1 } \\
\text { MB2 } \\
\text { MB3 }\end{array}$ \\
\hline $\begin{array}{l}\text { Minat } \\
\text { Unduhan } \\
\text { Musik dari } \\
\text { Internet/ } \\
\text { Website } \\
\text { Secara } \\
\text { Gratis }\end{array}$ & 4 & $\begin{array}{l}\text {-Tidak } \\
\text { mengeluarkan } \\
\text { biaya dalam } \\
\text { mengunduh } \\
\text { musik. } \\
\text {-Sulit dalam } \\
\text { mencari kualitas } \\
\text { suara musik } \\
\text { yang } \text { original. }\end{array}$ & $\begin{array}{l}\text { MG1 } \\
\text { MG2 }\end{array}$ \\
\hline
\end{tabular}

\section{B. Pengujian Validitas}

Pengujian validitas yang dimana dilakukan perbandingan antara nilai Pearson Product Moment pada setiap pertanyaan-pertanyaan atau indikator dengan nilai $r$ tabel. Jika Pearson Product
Moment ( $\mathrm{r}$ hitung) lebih besar dari nilai $\mathrm{r}$ tabel, maka indikator dari variabel dapat dikatakan valid. Nilai pada $r$ tabel pada penelitian ini sebesar 5\% yaitu r tabel pada penelitian ini mempunyai nilai 0,325 dengan perhitungan sampel responden sebesar 37. Nilai Pearson Product Moment pada setiap indikator atau pertanyaan harus berada diatas 0,325 agar indikator yang digunakan pada penelitian ini dapat dikatakan valid. Hasil dari pengujian validitas dapat dilihat pada Tabel 3 .

Tabel 3 Hasil Uji Validitas

\begin{tabular}{|l|l|l|l|}
\hline $\begin{array}{l}\text { Indikato } \\
\mathbf{r}\end{array}$ & $\begin{array}{l}\text { Pertanyaa } \\
\mathbf{n}\end{array}$ & $\begin{array}{l}\mathbf{R} \\
\text { hitun } \\
\mathbf{g}\end{array}$ & $\begin{array}{l}\text { Valid/tida } \\
\text { k valid }\end{array}$ \\
\hline MB1 & $\begin{array}{l}\text { Pertanyaan } \\
1\end{array}$ & 0,802 & Valid \\
\cline { 2 - 4 } & $\begin{array}{l}\text { Pertanyaan } \\
2\end{array}$ & 0,722 & Valid \\
\hline MB2 & $\begin{array}{l}\text { Pertanyaan } \\
3\end{array}$ & 0,629 & Valid \\
\cline { 2 - 4 } & $\begin{array}{l}\text { Pertanyaan } \\
4\end{array}$ & 0,703 & Valid \\
\cline { 2 - 4 } & $\begin{array}{l}\text { Pertanyaan } \\
5\end{array}$ & 0,672 & Valid \\
\hline \multirow{5}{*}{ MB3 } & $\begin{array}{l}\text { Pertanyaan } \\
6\end{array}$ & 0,595 & Valid \\
\cline { 2 - 4 } & $\begin{array}{l}\text { Pertanyaan } \\
7\end{array}$ & 0,617 & Valid \\
\hline \multirow{5}{*}{ MG1 } & $\begin{array}{l}\text { Pertanyaan } \\
8\end{array}$ & 0,802 & Valid \\
\cline { 2 - 4 } & $\begin{array}{l}\text { Pertanyaan } \\
9\end{array}$ & 0,722 & Valid \\
\hline \multirow{5}{*}{ MG2 } & $\begin{array}{l}\text { Pertanyaan } \\
10\end{array}$ & 0,486 & Valid \\
\cline { 2 - 4 } & $\begin{array}{l}\text { Pertanyaan } \\
11\end{array}$ & 0,517 & Valid \\
\hline
\end{tabular}

Dapat dilihat pada Tabel 3 dari hasil pengujian validitas pada penelitian ini, bahwa indikator pada MB1, MB2, MB3, MG1, dan MG2 berada diatas nilai $r$ tabel maka data dapat dinyatakan valid.

\section{Pengujian Reliabilitas}

Pengujian reliabilitas yang dimana dilakukan membandingkan nilai Cronbach's Alpha untuk 4 indikator sebanyak 11 pertanyaan dan total sampel yang berjumlah 37 responden. Standar nilai pada Cronbach's Alpha adalah diatas 0,6. 
Hasil dari pengujian reliabilitas dapat dilihat pada Tabel 4.

Dapat dilihat bahwa pada Tabel 4 dari hasil pengujian reliabilitas pada penelitian ini, nilai Cronbach's Alpha pada semua indikator berada diatas 0,6 sehingga ini menunjukkan data tersebut adalah data yang reliabel.

Tabel 4 Hasil Uji Reliabilitas

\begin{tabular}{|l|l|l|}
\hline Indikator & Pertanyaan & $\begin{array}{l}\text { Cronbach's } \\
\text { Alpha }\end{array}$ \\
\hline MB1 & Pertanyaan 1 & 0,832 \\
\cline { 2 - 3 } & Pertanyaan 2 & 0,839 \\
\hline MB2 & Pertanyaan 3 & 0,846 \\
\cline { 2 - 3 } & Pertanyaan 4 & 0,840 \\
\cline { 2 - 3 } & Pertanyaan 5 & 0,846 \\
\hline MB3 & Pertanyaan 6 & 0,849 \\
\cline { 2 - 3 } & Pertanyaan 7 & 0,847 \\
\hline MG1 & Pertanyaan 8 & 0,832 \\
\cline { 2 - 3 } & Pertanyaan 9 & 0,839 \\
\hline \multirow{2}{*}{ MG2 } & Pertanyaan 10 & 0,865 \\
\cline { 2 - 3 } & Pertanyaan 11 & 0,863 \\
\hline
\end{tabular}

\section{Pengujian Kuesioner}

Pengujian hipotesis yang dimana pengujian ini menggunakan Uji Independent Sample T-Test. Uji Independent Sample T-Test ini digunakan untuk membandingkan rata-rata dari dua buah variabel yang berbeda. Untuk Uji Independent Sample T-Test ini dilakukan dengan melihat nilai signifikan pada pengujian ini. Jika nilai signifikan berada dibawah nilai 0,05 maka Ha diterima dan H0 ditolak, dan jika nilai signifikan berada diatas nilai 0,05 maka $\mathrm{Ha}$ ditolak dan $\mathrm{H} 0$ diterima. Dalam penelitian ini peneliti akan menggunakan alat bantu komputer yaitu adalah aplikasi SPSS. Berikut adalah hasil dari Uji Independent Sampel T-Test. Hasil dari pengujian Independent Sample T-Test dapat dilihat pada Tabel 5.

Tabel 5 Uji Independent Sample T-Test

\begin{tabular}{|l|l|l|l|}
\hline & $\mathrm{F}$ & $\mathrm{t}$ & $\begin{array}{l}\text { Nilai } \\
\text { Signifikan }\end{array}$ \\
\hline $\begin{array}{l}\text { Total } \\
\text { Equal } \\
\text { variances } \\
\text { assumed }\end{array}$ & 0,032 & 10,802 & 0,000 \\
\hline $\begin{array}{l}\text { Equal } \\
\text { variances }\end{array}$ & & 10,802 & 0,000 \\
\hline
\end{tabular}

not

assumed

Dapat dilihat pada Tabel 5 dari Total Equal variances di asumsikan bahwa nilai signifikan dari Uji Independent Sampel TTest ini bernilai 0,000 yang artinya adalah hipotesis H0 ditolak dan hipotesis $\mathrm{Ha}$ diterima. Dari hasil pengujian ini dapat dikatakan minat aplikasi unduhan musik Spotify berbayar lebih besar dari pada minat unduhan musik dari internet/website secara gratis.

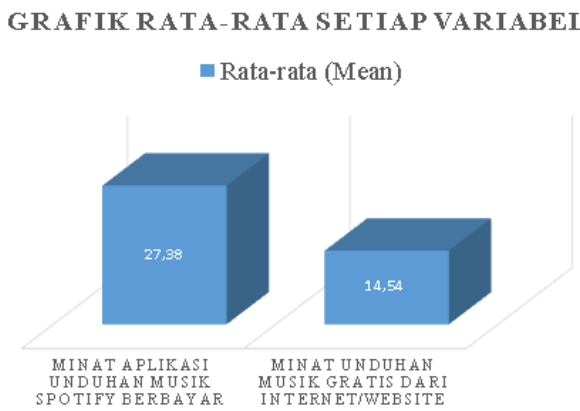

\section{Gambar 3 Grafik Rata-rata Variabel}

Dapat dilihat dari Gambar 3 bahwa rata-rata (Mean) dari variabel minat aplikasi unduhan musik Spotify berbayar mempunyai rata-rata sebesar 27.38 dan variabel minat unduhan musik gratis dari internet/website mempunyai rata-rata sebesar 14,54. Pada penelitian minat ini dapat disimpulkan bahwa minat aplikasi unduhan musik Spotify berbayar lebih besar dari pada minat unduhan musik dari internet/website secara gratis.

\section{KESIMPULAN}

Kesimpulan yang dapat diambil dari penelitian minat mahasiswa ini adalah:

1. Dari hasil analisis minat ini, variabel minat aplikasi unduhan musik Spotify berbayar mempunyai nilai 27,38 yang lebih besar dari pada variabel minat unduhan musik dari internet/website secara gratis yang mempunyai nilai 14,54 .

2. Dari hasil uji Independent Sample TTest telah didapat nilai signifikan dengan nilai 0,000 yang artinya 
hipotesis $\mathrm{H} 0$ ditolak dan hipotesis $\mathrm{Ha}$ diterima.

3. Disimpulkan bahwa mahasiswa Universitas Bunda Mulia lebih memilih mendengarkan aplikasi unduhan musik Spotify berbayar.

\section{DAFTAR PUSTAKA}

Juansyah, A, 2015, Pembangunan Aplikasi Child Tracker Berbasis AssistedGlobal Positioning System (A-GPS) Dengan Platfom Android, Jurnal Ilmiah Komputer dan Informatika (KOMPUTA).

Khairunizam, Danuri, Jaroji, 2017, Aplikasi Pemutar Musik Menggunakan Speech Recognition, Jurnal Inovtek Polbeng-Seri Informatika.

Kusumah, R, Ariyanti, M, Sumrahadi, 2017, Analis Perbandingan Positioning Aplikasi Musik Digital Berdasarkan Pendenkatan Pengalaman Pengguna (Studi Pengguna i - Tunes, Joox, Melon dan Spotify), $E-$ Proceeding of Management, vol 4, hal 2511-2518.

Luck, G, 2016, The Psychology of Streaming: Exploring Music Listeners' Motivations to Favour Access Over Ownership, International Journal of Music Business Research.

Pangastuti, D, 2015, Pengaruh Musik Dangdut Terhadap Perkembangan Bahasa Anak Di TK Dharma Wanita Madiun 2014/2015, Seminar Nasional Pendidikan UNS \& ISPI Jawa Tengah.

Pibriana, D, Ricoida, I, D, 2017, Analisis Pengaruh Penggunaan Internet Terhadap Minat Belajar Mahasiswa, JATISI.

Purnomo, A, Hartono, R, Hartatik, Riasti, K, B, Hidayah, N, I, 2016, Pengembangan Aplikasi Info Lagu Nusantara Berbasis Android Untuk
Melestarikan Warisan Budaya Indonesia, Jurnal SIMETRIS.

Sonang, S, 2013, Perencanaan dan Pembuatan Aplikasi Pemutaran MP3 Dengan Menggunakan Bahasa Delphi, Jurnal Murni Sadar.

Sutangi H, 2014, Hubungan Pengetahuan Dan Sikap Ibu Dengan Kejadian Pneumonia Balita Di Desa Telukagung Wilayah Kerja Uptd Puskesmas Plumbon Kecamatan Indramayu Kabupaten Indramayu Tahun 2014, Jurnal Kesehatan Masyarakat (AFIASI). 